\section{Islanders flee surprise eruption}

Tokyo

JAPAN's volcanologists were taken by surprise when Mount Mihara on Izu-Oshima island south of Tokyo exploded in a series of violent eruptions last Friday, forcing the overnight evacuation of the island's 10,000 inhabitants as a river of lava threatened to engulf the main town.

Izu-Oshima is the first in a chain of volcanic islands that extends southward for more than $1,000 \mathrm{~km}$ into the Pacific along the edge of the Philippine plate. A submarine volcano at the southernmost end of the volcanic arc temporarily broke surface during an eruption earlier this year (Nature 319, 441; 1986), and Miyakejima, Izu Oshima's immediate neighbour, erupted in 1982. But Izu-Oshima itself has been silent for the past 12 years, and an eruption on the present scale has not occurred in the past two centuries.

The first signs of activity came in July when the island was rocked by volcanic tremors. But surveys by the Meteorological Agency and Tokyo University's Earthquake Research Institute showed no evidence of the 'bulging' of the Earth's crust

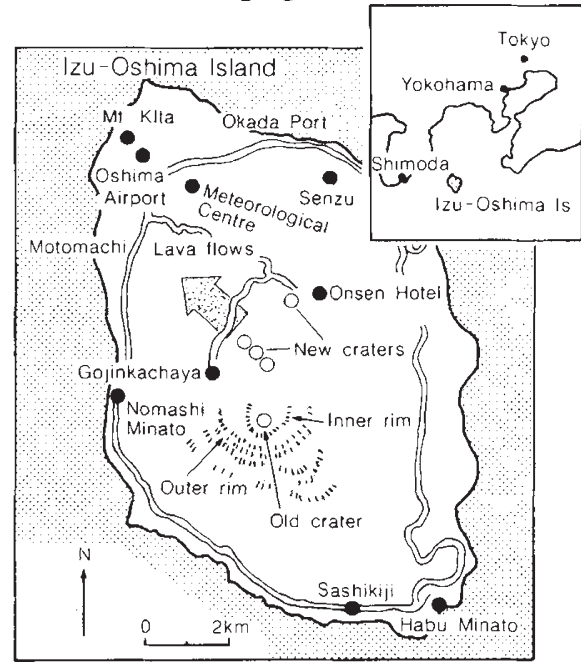

that typically precedes major eruptions as magma rises to the surface. And at the end of October the Volcanic Eruptions Prediction Liaison Council declared that there were no signs that a large-scale eruption was imminent.

Even after eruptions began on 15 November, the council confidently predicted that lava flows would be confined to the caldera by the outer rim of the volcano, and Oshima enjoyed a temporary boom as hundreds of tourists flocked to the island each day to enjoy the spectacular eruption and lava flows.

After 10 million cubic metres of lava had spilled over the inner rim of the volcano and the rivulets of lava in the caldera had frozen in their path, the Meteorological Agency announced that activity appeared to be decreasing and the island's residents were in no immediate danger. Hours later the evacuation order came.

What nobody had foreseen was the opening of a new line of vents that cut through the outer rim, something that had not occurred in more than 500 years. As the new vents burst into life, lighting up the night sky in a curtain of fire, a river of lava set forests ablaze as it surged towards the main town of Motomachi.

\section{Biotechnology insured}

Washington

THE high cost of US product liability insurance has stimulated the Association of Biotechnology Companies (ABC) to plan a captive cooperative insurance company for the industry. If enough companies join the risk-sharing enterprise, it could offer "attractive" rates for insurance in respect of product liability as well as for the actions of directors and officers of companies, according to Bruce Mackler, ABC's general counsel.

Many smaller biotechnology companies have apparently not been able to obtain insurance at reasonable cost; some have had to proceed with none. $\mathrm{ABC}$ says one (unnamed) biotechnology company was recently quoted an annual premium of $\$ 400,000$ for total coverage of $\$ 1$ million.

Part of the difficulty is the recent inflation of product liability claims, and of insurance premiums. The insurance industry is also under pressure from the number of product liability suits in federal courts, up by 750 per cent since 1974 , and the average jury award, which has risen from $\$ 400,000$ to more than $\$ 1.8$ million during the same period, according to the American Insurance Association.

Insurers are especially fearful of the doctrine, recently introduced in California, of "joint and several liability", which means that a party only partly at fault can be obliged to become the "deep pocket" from which a whole claim must be met. Chemical, pharmaceutical, aircraft and car manufacturers are most at risk.

This, say insurance companies, is why they prefer to stick to the devils they know, such as automobile insurance and workers' compensation, than to take on unknown quantities such as biotechnology. They fear that huge claims may be made in the light of future knowledge, as they have been for medical products, when initial ignorance of harmful effects may not be a defence.

The ABC scheme was recommended by a study conducted by insurance brokers Johnson and Higgins of New York. Twenty-four companies from around the
By dawn the island was deserted, the 10,000 residents and 2,000 tourists having been evacuated to the mainland. All that remained were abandoned domestic animals, a farmer who stubbornly refused to leave his 5,000 chickens, and some baffled volcano experts.

On Monday, the lava front lay within a few hundred metres of Motomachi, but volcanic activity seemed to have switched to the southeast coast of the island, where plumes of discoloured water in the sea suggest submarine volcanic activity.

David Swinbanks

\title{
Response to product liability
}

world, including well-known companies such as Celltech and Charles River, have chipped in enough to establish the biotechnology insurance cooperative legally in the state of Vermont; it should be ready for "activation" by early December. Membership will be open to any company in the field, but 30 members will be required to make it viable. The Industrial Biotechnology Association, which represents generally larger companies, has considered and rejected such a scheme, as many of its members are able to carry their own insurance.

The ABC captive insurer will provide only modest coverage at the outset: $\$ 1$ million of either primary or "excess" coverage, with an aggregate ceiling of $\$ 3$ million. But coverage would increase if the scheme expands; 44 companies have asked for quotes. $\mathrm{ABC}$ hopes the scheme will include insurance against environmental damage for such products as mic-

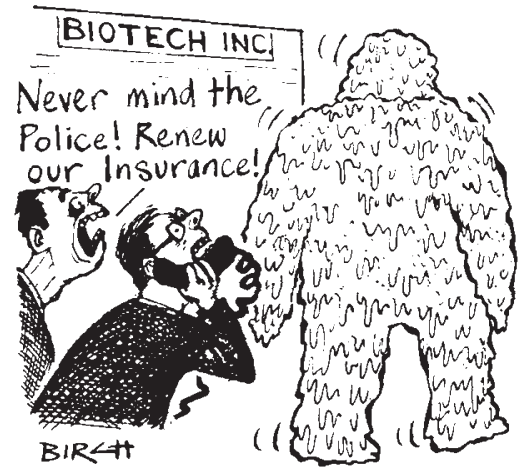

robial pesticides, but admits that may be expensive. All participants will be inspected by risk management experts to ensure they are "doing things by the book".

The American Insurance Association is generally sceptical of captive insurers, saying that insurance costs reflect the costs of meeting claims, no matter who does the underwriting. The insurance industry says that the provision of medical malpractice insurance through similar "risk retention groups" is now as expensive as through commercial agents.

Tim Beardsley 